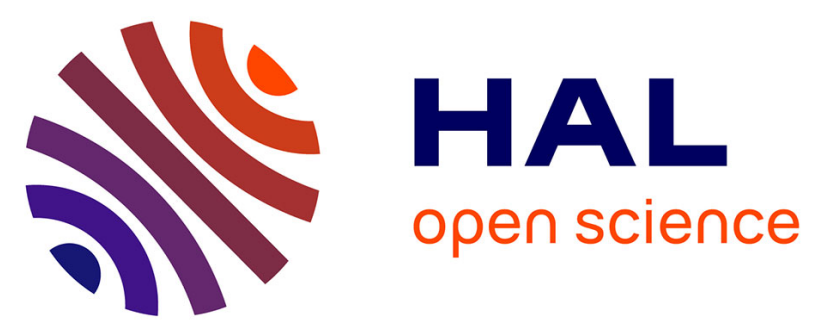

\title{
Impact of spray-drying conditions on physicochemical properties and rehydration ability of skim dromedary and cow's milk powders
}

Imène Felfoul, Jennifer Burgain, Carole Perroud, Claire Gaiani, Joël Scher, Hamadi Attia, Jérémy Petit

\section{To cite this version:}

Imène Felfoul, Jennifer Burgain, Carole Perroud, Claire Gaiani, Joël Scher, et al.. Impact of spraydrying conditions on physicochemical properties and rehydration ability of skim dromedary and cow's milk powders. Drying Technology, 2020, pp.1-13. 10.1080/07373937.2020.1828448 . hal-03059297

\section{HAL Id: hal-03059297 \\ https://hal.univ-lorraine.fr/hal-03059297}

Submitted on 16 Apr 2021

HAL is a multi-disciplinary open access archive for the deposit and dissemination of scientific research documents, whether they are published or not. The documents may come from teaching and research institutions in France or abroad, or from public or private research centers.
L'archive ouverte pluridisciplinaire HAL, est destinée au dépôt et à la diffusion de documents scientifiques de niveau recherche, publiés ou non, émanant des établissements d'enseignement et de recherche français ou étrangers, des laboratoires publics ou privés.

\section{(ㄷ)(1) $\$$}

Distributed under a Creative Commons Attribution - NonCommerciall 4.0 International 
Impact of spray-drying conditions on physicochemical properties and rehydration ability of skim dromedary and cow's milk powders

3

4 Imène FELFOUL ${ }^{a^{*}}$, Jennifer BURGAIN ${ }^{\mathbf{b}}$, Carole PERROUD ${ }^{\mathbf{b}}$, Claire GAIANI ${ }^{\mathrm{b}}$, Joël

5 SCHER $^{\mathrm{b}}$, Hamadi ATTIA ${ }^{\mathrm{a}}$, Jérémy PETIT ${ }^{\mathrm{b}}$

*Corresponding author. Tel.: +21622048 253

10 a Université de Sfax, Laboratoire Analyses, Valorisation et Sécurité des Aliments (LAVASA),

11 Ecole Nationale d'Ingénieurs de Sfax, Route de Soukra, 3038 Sfax, Tunisia.

12 b Université de Lorraine, LIBio (Laboratoire d'Ingénierie des Biomolécules), F-54000 Nancy, 13 France. 


\section{ABSTRACT}

17 The effect of spray-drying conditions on physicochemical and rehydration ability of

18 skim dromedary and cow's milk powders was evaluated. Two sets of spray-drying conditions

19 were applied on skim dromedary and cow's milks to determine the effect of air outlet

20 temperature $\left(75\right.$ and $\left.85^{\circ} \mathrm{C}\right)$ and milk type on proximate composition, water activity, particle

21 size distribution, color, and rehydration ability of spray-dried powders. While the water activity of powders was close to 0.4 for a production at $75^{\circ} \mathrm{C}$ air outlet temperature, it ranged from 0.2 to 0.3 for a production at $85{ }^{\circ} \mathrm{C}$ air outlet temperature. Skim dromedary milk powder had a

24 lower water activity than skim cow's milk powder after spray-drying at $85{ }^{\circ} \mathrm{C}$ air outlet 25 temperature. The particle size distributions of spray-dried skim milk powders were centered 26 around $14-20 \mu \mathrm{m}$. The particles of skim dromedary milk powders were smaller than those of 27 skim cow's milk powders as skim dromedary milk was less viscous, leading to smaller sprayed droplets. Whatever the spray-drying conditions and the milk type, the produced powders were very bright and had a low color saturation. Scanning electron microscopy images showed that spray-dried powders appeared as agglomerates of small particles with angular shapes rather

31 than individual particles. All investigated spray-dried powders were considered non-wettable,

32 hardly dispersible, and fairly soluble. These results demonstrated that the outlet drying air temperature significantly influenced the physical and rehydration properties of spray-dried 34 dairy powders.

36 Keywords: spray-drying; dromedary milk; water activity; particle size distribution; rehydration ability; SEM 


\section{INTRODUCTION}

In recent years, a great attention has been paid to the health benefits of dromedary milk, which constitutes an important nutrition source for inhabitants in arid and semi-arid areas. ${ }^{[1]}$ Dromedary milk has been proven to contain great amounts of essential fatty acids, vitamin C as well as natural immune-active proteins such as lactoferrin, lysozyme, immunoglobulins, and lactoperoxidase. ${ }^{[2]}$ The proximate composition of cow's and dromedary milks is similar. However, dromedary milk is higher in B-casein and lower in $\mathrm{K}$-casein, making it less suitable for cheesemaking. Moreover, B-lactoglobulin, which is very important for infant nutrition, is absent from dromedary milk. ${ }^{[3]}$

The preservation of dromedary milk involves many processes such as thermal treatment ${ }^{[4,5]}$, acid coagulation ${ }^{[6]}$, and microbiological fermentation ${ }^{[7]}$. Many derivative products of dromedary milk have been developed, such as butter ${ }^{[8]}$ and yogurt. ${ }^{[9]}$ Although these products are stable, they have a short shelf-life due to their sensitivity to physicochemical, biochemical, and microbiological degradations during storage. ${ }^{[10]}$ Therefore, the production of dromedary milk powders could contribute to increase the shelf-life of milk derivatives.

Spray-drying is the most used drying process in all food sectors including dairy products, cereals, vegetables, and eggs. ${ }^{[1-13]}$ Spray-drying is a matured drying technique with a still significant potential for continued development. ${ }^{[14]}$ The spray-drying process is suitable to dry dairy products due to the short drying time and the ability to obtain a powdered product. ${ }^{[15]}$ In the dairy industry, spray-drying is employed not only to increase the stability of milk products during their storage, but also to facilitate their later use. As observed for bovine milks, the spray-drying process is an excellent option for extending the shelf-life of dromedary milk by converting milk into powder without much changing its nutritional and sensory characteristics. ${ }^{[15,16]}$ 
However, to the best of our knowledge, only few studies have investigated the impact of spray-drying on dromedary milk properties. ${ }^{[17,18]}$ Smits et al. ${ }^{[19]}$ have shown that spray-drying of raw whole dromedary milk did not cause any noticeable damage to its protein fraction and al. ${ }^{[20]}$ have reported that the spray-drying process induces a mild heat treatment, preserving the protein quality of dromedary and cow's milks.

Most of these studies have focused on the evaluation of the physicochemical properties

of dromedary milk powders. The number of studies about the influence of spray-drying conditions is very limited. In fact, Zouari et al. ${ }^{[21]}$ studied the effect of air outlet temperature and milk fat content on the physicochemical characteristics of spray-dried dromedary milk powder. Recently, Habtegebriel et al. ${ }^{[16]}$ investigated the effect of pretreatments of the feed concentrate prior to spray-drying on cyclone recovery and the physicochemical properties of dromedary milk powders. These authors reported that operating at less severe processing temperature during spray-drying is necessary to retain higher solubility of dromedary milk proteins. They also showed that dromedary milk powders had higher bulk densities than cow's milk powders processed under similar drying conditions. Furthermore, Ogolla et. al. ${ }^{[22]}$ studied the influence of inlet drying air temperature and milk flow rate on the physical, optical, and thermal properties of spray-dried dromedary milk powders. They reported that the inlet drying air temperatures significantly influenced moisture content and the color properties of the 82 powders. Indeed, with the increase in inlet drying air temperatures and a decrease in milk flow 83 rate, the moisture content and the brightness of dromedary milk powders significantly

84 decreased. They also showed that particle morphology was affected by the nature and 85 composition of the feed, degree of heat treatment, and spray-drying parameters (inlet drying air temperature and milk flow-rate). ${ }^{[22]}$ 
milk powder. The properties of cow's milk powder vary considerably depending on the type and composition of the powder, as well as the process conditions of concentration and drying 90 processes. ${ }^{[23]}$ The reconstitution properties of cow's milk powder such as solubility, wettability, 91 and dispersibility are mainly affected by the inlet drying air temperature and the dry extract of 92 the feed concentrate. ${ }^{[23]}$

93 In the present study, two sets of spray-drying process conditions were applied on skim 94 dromedary and cow's milks to evaluate the impact of process conditions and milk type on physicochemical properties (proximate composition, water activity, particle size distribution, and color) and rehydration ability of spray-dried powders.

\section{MATERIAL AND METHODS}

\section{Dromedary and cow's milks}

Dromedary (Camelus dromedarius) milk was obtained from a local breeding located in the south of Tunisia (Gabès governorate, Tunisia). Dromedary milk constituted of pooled milk samples assembled from twenty different healthy dromedaries, whose lactation time ranged between 2 and 8 months. As for the cow's milk, which was provided by a farm located in the north-east of France (experimental domain of La Bouzule, ENSAIA, Laneuvelotte, France), it was collected from healthy Holstein cows. Both milks were collected in sterile milking cans and $0.02 \%(\mathrm{w} / \mathrm{w})$ sodium azide was added to ensure their microbiological stability. Both milks were skimmed at $3000 \times \mathrm{g}$ during $20 \mathrm{~min}$ at $4{ }^{\circ} \mathrm{C}$ (Gyrozen 1580MGR, Multi-purpose

107 Centrifuge, Daejeon, Korea). Then, both skim milks were stored at $-20^{\circ} \mathrm{C}$ until use for spray108 drying. 
111 Skim dromedary and cow's milks were sieved at $50 \mu \mathrm{m}$ mesh size (stainless steel, 200

$112 \mathrm{~mm}$ diameter, $50 \mathrm{~mm}$ height, Retsch $\mathrm{GmbH}$, Germany) in order to remove the potential

113 remaining coalesced fat globules. The spray-drying of skim milks was performed in a

114 MicraSpray MS 150 simple effect pilot plant spray-dryer (Anhydro, Soeborg, Danemark)

115 equipped with a bi-fluid nozzle (Fluid Cap 60100 + Air Cap 120, Spraying System, Wheaton,

116 Illinois, USA). Aspiration rate was set at $70 \%$ for all performed assays, corresponding to 155

$117 \mathrm{~kg} \cdot \mathrm{h}^{-1}$ drying air flow rate. The spray-dryer was fed at $27^{\circ} \mathrm{C}$ with a FAST Load peristaltic pump

118 (VWR, Leuven, Belgium, $48 \mathrm{~mm}$ internal pipe diameter). The drying air cocurrently flowed

119 with the spray of milk droplets in the drying chamber (Figure 1). Two assays differing in spray-

120 drying conditions (30 L milk per assay) were carried out with a view to evaluate the influence

121 of air outlet temperature (Table 1). The spray-drying conditions were selected based on

122 literature ${ }^{[11]}$ and after preliminary experimentations in order to obtain skim milk powders

123 suitable for storage (i.e. having a moisture content not exceeding $5 \%(w / w)$ and water activity

124 values ranging between 0.2 and 0.4$) \cdot{ }^{[11]}$

125 The powders were then collected, immediately packed in polyethylene terephthalate

126 bags and stored at $10^{\circ} \mathrm{C}$ until analysis. All analyses were carried out within a week after powder

127 production. Spray-drying yield was calculated as the ratio between the dry mass of powder and 128 the dry mass of feed skim milk.

132 performed according to the AOAC standard methods. ${ }^{[24]}$ Dry matter was determined by drying $13310 \mathrm{~mL}$ milk at $103{ }^{\circ} \mathrm{C}$ for $5 \mathrm{~h}$ in a capsule containing Fontainebleau sand $(1: 10(\mathrm{w} / \mathrm{w})$ milk 134 sample/Fontainebleau sand). Ash content was determined by weight loss after incinerating 10 $135 \mathrm{~mL}$ milk sample in a furnace at $550{ }^{\circ} \mathrm{C}$ during $6 \mathrm{~h}$. The total nitrogen content was determined 
according to Kjeldhal method (10 $\mathrm{mL}$ of milk sample), and protein content was deduced from total nitrogen content by multiplying by a conversion factor of 6.38 . Fat content was determined according to the Gerber acid-butyrometric method (11 mL of milk sample). Carbohydrates content was deduced by difference with other components according to equation 1 assuming that vitamins were weakly represented:

$$
\begin{aligned}
& \text { Carbohydrates content }(\%)=100- \\
& (\text { moisture content }+ \text { protein content }+ \text { ash content }+ \text { fat content })
\end{aligned}
$$

(Equation 1)

\section{Dynamic viscosity of skim dromedary and cow's milks \\ The dynamic viscosity of dromedary and cow's skim milks was determined at $4{ }^{\circ} \mathrm{C}$ using the Malvern Kinexus oscillatory rheometer (Malvern Instruments, Orsay, France) using cone-plane geometry at shear rates ranging from 0.1 to $1000 \mathrm{~s}^{-1}$ during $20 \mathrm{~min}$.}

\section{Proximate composition of skim dromedary and cow's milk powders}

Moisture, protein, and ash contents of skim dromedary and cow's milk powders were performed according to the AOAC standard methods. ${ }^{[24]}$ Moisture content was determined by weight loss after drying $3 \mathrm{~g}$ powder in an air oven at $105^{\circ} \mathrm{C}$ for $7 \mathrm{~h}$. Ash content was obtained by weight loss after incinerating $3 \mathrm{~g}$ powder in a furnace at $550{ }^{\circ} \mathrm{C}$ during $6 \mathrm{~h}$. The total nitrogen content was determined by the Kjeldahl method ( $0.1 \mathrm{~g}$ of milk powder) (Vapodest, Gerhardt GmbH \& Co. KG, Königswinter, Germany) and protein content was deduced from nitrogen content by multiplying by a conversion factor of 6.38 .

Fat content was determined using the Folch method ${ }^{[25]}$ by performing solvent extraction of $2 \mathrm{~g}$ powder using a mix of $2: 1(\mathrm{v} / \mathrm{v})$ chloroform $/$ methanol. Carbohydrates content was deduced by difference with other components according to equation 1 assuming that vitamins were weakly represented.

\section{Water activity}


Water activity of spray-dried powders ( $10 \mathrm{~g})$ was measured using a water activity meter

163 (HygroPalm23-AW, Rotronic, France) in quick mode at $25^{\circ} \mathrm{C}$.

164

165

166

\section{Particle size distribution}

Particle size distributions of skim dromedary and cow's milk powders were determined

with a laser granulometer (Mastersizer 3000 Malvern Instruments, UK), equipped with He-Ne laser light (632.8 $\mathrm{nm}$ wavelength), using dry dispersion with the Aero S module. Dispersion conditions were as follows: 2 bar, $100 \%$ air pressure, $100 \%$ feed rate, and $3 \mathrm{~mm}$ hopper length.

The median diameter in volume was chosen as particle size estimator. Classical granulometric

171 parameters $D_{10}, D_{50}$, and $D_{90}$ were recorded $\left(D_{X}\right.$ corresponds to the size for which $X \%$ of the 172 particle population has smaller size). Span was calculated to evaluate the width of the particle size distribution (equation 2):

$$
\text { Span }=\left(D_{90}-D_{10}\right) / D_{50}(\text { Equation } 2)
$$

\section{Colorimetric analysis}

The color of skim dromedary and cow's milk powders was measured using a colorimeter

177 (Konica Minolta, Inc, Japan) in the CIEL*a*b* system. The colorimetric parameters L* (lightness), a* (redness/greenness), and b* (yellowness/blueness) were determined. L*, varying 179 from 0 to 100, describes sample lightness (low values for darkness, high values for lightness).

$180 \mathrm{a}^{*}$ varies from -100 to 100 and represents the green-magenta color scale, with negative values 181 for greenness and positive values for redness. $b^{*}$ ranges from -100 to 100 and corresponds to 182 the blue-yellow color scale, with negative values for blueness and positive values for 183 yellowness. The chroma $\left(\mathrm{C}^{*}\right)$ and hue angle $\left(\mathrm{H}^{\circ}\right)$, representing the saturation level and shade 184 of the color, respectively, were calculated as follows (equations 3 and 4). ${ }^{[26]}$

$$
C^{*}=\sqrt{a^{*^{2}}+b^{* 2}} \text { (Equation 3) }
$$




$$
H^{\circ}=\arctan \left(b^{*} / a^{*}\right)(\text { Equation } 4)
$$

\section{Scanning electron microscopy}

The morphological properties of skim dromedary and cow's milk powders were

determined using scanning electron microscopy (Hitachi S-4800, Japan) operated at $1 \mathrm{kV}$.

192 Powders were stuck onto the adhesive carbon tabs (JEE-420, Japan). The milk powder samples

193 were then coated with carbon. Topographic images were taken for each milk powder at different

194 magnifications $(200 \times, 600 \times, 2000 \times, 10000 \times$, and $45000 \times)$.

195

196

197

198

199

200

201

202

203

204

205

206

207

208

209

210

211

\section{Rehydration properties}

\section{Solubility index}

Solubility represents the mass percentage of soluble matter in powders, it was determined according to ISO 8156:2005 standard method. ${ }^{[27]}$ First, $2.5 \mathrm{~g}$ skim milk powder was vigorously mixed with $17.5 \mathrm{~mL}$ distilled water at $22{ }^{\circ} \mathrm{C}$ in a Falcon tube during $30 \mathrm{~s}$. The suspension was then centrifuged at $1800 \times g$ (Heraeus Megafuge 8R Centrifuge, Germany) at room temperature $\left(22^{\circ} \mathrm{C}\right)$ and the supernatant was collected. The supernatant dry matter was determined by drying at $103{ }^{\circ} \mathrm{C}$ in an air oven for $15 \mathrm{~h}$. The solubility index SI was determined using the following equation 6 :

$$
S I(\%)=100-(M * 100 / 2.5)(\text { Equation } 6)
$$

Where $\mathrm{M}$ designates the sediment mass $(\mathrm{g})$.

\section{Wetting time}

The wetting time is defined as the time expressed in seconds required for a powder to become completely wet. ${ }^{[28]}$ It was determined by gently pouring 26 g powder at the surface of $250 \mathrm{~g}$ distilled water at $20^{\circ} \mathrm{C}$ in a $250-\mathrm{mL}$ beaker.

\section{Dispersibility index}


212 The dispersibility index (DI) is the amount of dry matter that can be dispersed in water, 213 expressed as a mass percentage. ${ }^{[28]}$ To evaluate the dispersibility index, $26 \mathrm{~g}$ powder was added 214 to $250 \mathrm{~g}$ distilled water at $20^{\circ} \mathrm{C}$ and the mixture was stirred with a spatula for $20 \mathrm{~s}$. A filtration 215 of the mixture was carried out using a metallic sieve. The dispersibility index DI was 216 determined using the following equation 7 :

$$
D I=\frac{T \times 962}{100-(W+T)} \text { Equation (7) }
$$

218 With T: dry matter content of the resulting liquid $(\%(\mathrm{w} / \mathrm{w}))$;

219 W: moisture content of the powder sample $(\%(\mathrm{w} / \mathrm{w}))$.

220

221

222

223

224

225

226

227

228

229

230

231

232

233

234

235 236

\section{Statistical analysis}

All analyses of this study were carried out in triplicate and reported values were means \pm standard deviations. Statistical analysis was performed using the DSAASTAT add-on for Excel 2010 (Microsoft, Redmond, USA). The presence of significant differences between sample results was investigated by one-way ANOVA and the means were separated by Tukey's HSD test at $\mathrm{p} \leq 0.05$.

\section{RESULTS AND DISCUSSION}

\section{Proximate composition of skim dromedary and cow's milks}

The proximate composition of skim dromedary and cow's milks is summarized in Table 2. The proximate composition was significantly different between milk samples. Total solids content was significantly lower for skim dromedary's milk $(9.52 \%(\mathrm{w} / \mathrm{w}))$ than for skim cow's milk $(12.05 \%(\mathrm{w} / \mathrm{w}))$. Protein and ash contents were significantly higher for skim dromedary's milk. Carbohydrates content was significantly lower in the case of skim dromedary's milk. These differences could be attributed to the milk type, animal feed, geographic location, and veterinary practices. ${ }^{[1]}$ Similar results were obtained by Al Haj and Al Kanhal ${ }^{[1]}$ who reported 
237 that ash content of dromedary milk ranged between 0.60 and $0.90 \%(\mathrm{w} / \mathrm{w})$ on dry basis. Zouari 238 et al. ${ }^{[21]}$ obtained similar results for proteins and ash but lower carbohydrates (lactose) content 239 for skim dromedary and cow's milks. The proximate composition of skim cow's milk obtained 240 in the current study was in agreement with the ranges of proximate composition of skim cow's 241 milk reported by other researchers ${ }^{[16]}$ Although both milks were skimmed in the current study, 242 the fat content of both samples was still higher than that usually observed for skim dromedary 243 and cow's milks. These results could be justified by the fact that the conditions used for milk

244 skimming by centrifugation in this study were soft compared to what is commonly realized in 245 the literature. Therefore, both milks were considered to be partially skim milks. higher air outlet temperature generally induces the formation of powder with a higher total

\section{Proximate composition of skim dromedary and cow's milk powders}

Table 3 displays proximate composition, water activity, and spray-drying yield for skim dromedary and cow's milk powders. Total solids content, ranging from 92.96 to $97.01 \%$ (w/w), significantly differed between all spray-dried skim milk powders. Both skim dromedary and cow's milk powders resulting from the second spray-drying assay led to the highest proportions of total solids ( 97.01 and $96.63 \%(\mathrm{w} / \mathrm{w})$, respectively). This was consistent with the fact that a solids content. ${ }^{[1]]}$ According to Chever et al. ${ }^{[29]}$, the total solids content of milk powder is affected by milk proximate composition, the air outlet temperature during spray-drying, and the residence time in the spray-dryer. It has also been reported that a small increase in the air outlet temperature during spray-drying can have a substantial effect on powder moisture content. In 260 for skim dromedary milk powder, Langrish et al. ${ }^{[3]}$ for skim cow's milk powder, and de 261 Oliveira et al. ${ }^{[32]}$ for whole goat milk powder. Spray-drying conditions did not have a significant 
262 impact on the proximal composition of studied milk powders. As it can be seen from Tables 2

263 and 3, the proximate compositions of skim milk powders are comparable to those of their

264 corresponding milks. Besides, protein contents of skim milk powders were neither significantly

265 affected by the milk type nor by spray-drying conditions. The protein contents reported for skim

266 dromedary milk powders spray-dried at 75 and $85{ }^{\circ} \mathrm{C}$ were equal to 22 and $23 \%$ (w/w),

267 respectively. The lower protein contents obtained for skim dromedary milk powders could be

268 attributed to the lower protein content of dromedary milk used to feed the spray-dryer.

269 Habtegebriel et al. ${ }^{[16]}$ showed that spray-dried skim dromedary milk powders contained 44 - 49

$270 \%(\mathrm{w} / \mathrm{w})$ proteins. The higher total lipids content of produced powders might explain the lower 271 content in proteins found in the present study. Although no significant difference was observed 272 in ash content between skim dromedary and cow's milks (Table 2), spray-drying process 273 conditions had a significant impact on ash content (Table 3). The ash contents of skim 274 dromedary milk powders of the current study were similar to the $10 \%(\mathrm{w} / \mathrm{w})$ ash content 275 reported by Habtegebriel et al. ${ }^{[16]}$ for skim dromedary milk powder. For skim cow's milk 276 powders, the obtained ash contents, ranging from 6.41 to $6.63 \%(\mathrm{w} / \mathrm{w})$, were a little lower than 277 those reported by Deeth and Hartanto ${ }^{[33]}$, ranging from 7.5 to $8.0 \%(w / w)$.

278 The water activity of spray-dried powders was mainly affected by spray-drying conditions. In fact, it was close to 0.4 at $75^{\circ} \mathrm{C}$ air outlet temperature, whereas it ranged between

$280 \quad 0.2$ and 0.3 at $85^{\circ} \mathrm{C}$ air outlet temperature. This was consistent with the fact that powder water 281 activity is negatively correlated with total solids content, ${ }^{[11]}$ which was also observed in this 282 study. Skim dromedary and cow's milk powders had close water activity after spray-drying at $28375^{\circ} \mathrm{C}$ air outlet temperature, but skim dromedary milk powder had a lower water activity than 284 skim cow's milk powder after spray-drying at $85^{\circ} \mathrm{C}$ air outlet temperature. Water activity is an 285 important parameter for food preservation. At water activities around 0.3, microbiological 286 growth, lipid oxidation, and Maillard reaction have very low reaction rates. ${ }^{[34]}$ It has been shown 
287 that a water activity between 0.2 and 0.3 at $25^{\circ} \mathrm{C}$ is suitable to achieve optimal stability of milk 288 powders. ${ }^{[34]}$ Therefore, in our study, it was noticed that the conditions of the second spray289 drying assay $\left(85^{\circ} \mathrm{C}\right.$ air outlet temperature) were more favorable to the preservation of skim 290 dromedary and cow's milk powders.

291 The spray-drying yield is an important parameter for the cost-effectiveness of food 292 preservation. For all spray-drying conditions, the process yields reported in this study (Table 3) seemed to be low for several reasons. Indeed, the pilot spray-dryer used in this study has a large wall area relative to the drying room volume compared to industrial equipment, which promotes material loss by wall sticking. Besides, the low total solids content of the feeding concentrate (skim milk here) contributes to the formation of small-sized particles. ${ }^{[35]}$ A non negligible proportion of the powder was therefore not retained by the cyclone and escaped with the outlet air. Finally, the presence of residual fat could also favor the stickiness of produced powders. ${ }^{[31]}$ Powder stickiness is the primary factor affecting the spray-drying yield. A sticky powder is able to adhere to the walls of the spray-drying chamber, enhancing material losses. Stickiness occurs when using drying temperatures slightly over the glass transition temperature of lactose in milks, i.e. in the temperature range comprised between lactose glass transition temperature $\left(55.6{ }^{\circ} \mathrm{C}\right)$ and about $30^{\circ} \mathrm{C}$ over.${ }^{[36]}$ Recently, Zouari et al. ${ }^{[21]}$ reported that using an air outlet temperature of $76.5{ }^{\circ} \mathrm{C}$, the glass transition temperatures were 40 and $37.8{ }^{\circ} \mathrm{C}$ for skim dromedary and cow's milk powders and $40{ }^{\circ} \mathrm{C}$, respectively. With the increase in air outlet temperature up to $86.8^{\circ} \mathrm{C}$, the same authors obtained glass transition temperatures of 44 and $41.5^{\circ} \mathrm{C}$ for skim dromedary and cow's milk powders, respectively. Based on these results, it can be concluded that the two air outlet temperatures used in our study were over the sticky points of skim dromedary and cow's milk powders, thus leading to a great proportion of powder loss by sticking to the spray-dryer walls. The residual fat and the fineness of produced powders could probably explain the low spray-drying yields. If the spray-drying operation lasted longer, 
312 the processing yields would have been improved because the spray-dryer walls would have

313 been covered with powder after a moment, which could thereafter limit the deposition of new

314 powder particles.

315 In the present study, spray-drying yields were greater at the higher air outlet temperature

$316\left(85^{\circ} \mathrm{C}\right)$, especially for skim dromedary milk powders $\left(51.26 \%\right.$ at $85{ }^{\circ} \mathrm{C}$ outlet air temperature

317 vs $19.81 \%$ at $75{ }^{\circ} \mathrm{C}$ outlet air temperature). Spray-drying yields were significantly negatively

318 correlated to water activity (Pearson's correlation coefficient $r$ of 0.94 ). Therefore, it was noted

319 that spray-drying conditions had a greater effect on dromedary milk powders. In accordance

320 with these results, De Oliveira et al. ${ }^{[32]}$ reported that higher yields are obtained at lower relative

321 humidity of the outlet air, i.e. when the outlet temperature is high and/or the feed flow-rate is

322 low. Habtegebriel et al. ${ }^{[16]}$ also reported that the increase in the air outlet temperature is likely

323 to enhance cyclone recovery. Actually, it can be predicted that it increases heat and mass

324 transfer in the drying air, thus improving the drying rate and limiting powder stickiness. Similar

325 results were reported by Gallo et al. ${ }^{[37]}$ who found that the drying air and feed flow-rates as well

326 as the outlet temperature are determinant for the spray-drying yield.

\section{Particle size distributions of skim dromedary and cow's milk powders}

Particle size distribution is a very important physical property of milk powders, known for its significant impact on the reconstitution properties of milk powders. Indeed, large particles within a narrow particle size distribution could enhance the rehydration properties of milk samples. ${ }^{[38]}$ Particle size distributions and granulometric parameters of spray-dried powders are respectively displayed in Figure 2 and Table 4, respectively.

The particle size distributions of spray-dried skim milk powders were monomodal and centered around $14-20 \mu \mathrm{m}$, consistently with previous results obtained with the same combination of pilot spray-dryer and bi-fluid nozzle. ${ }^{[39,40]}$ The dispersion of particle sizes around the median value was relatively low, as indicated by the moderate values of span ranging 
337 from 1.75 to 1.93 . Although the spray-drying conditions seemed not to influence the particle 338 size distribution, it was noted that the particles of skim dromedary milk powder were smaller 339 than those of skim cow's milk powders. Furthermore, the higher total solids content of feed 340 skim cow's milk may justify this result. Indeed, its viscosity was higher (3.89 $\pm 0.12 \mathrm{mPa} . \mathrm{s})$ 341 than that of feed skim dromedary milk $(2.96 \pm 0.13 \mathrm{mPa} . \mathrm{s})$ (Table 2), leading to larger sprayed 342 droplets ${ }^{[35]}$ resulting in larger spray-dried particles. Another cause may be attributed to the 343 higher fat content of skim cow's milk powder, which makes it stickier. In fact, fat, composed 344 of sticky components (with a fusion temperature inferior to $80^{\circ} \mathrm{C}$ ), is known to concentrate at 345 particle surface during spray-drying due to buoyancy in sprayed droplets, ${ }^{[41-44]}$ making them 346 more prone to agglomeration, thus leading to particle size increase. According to Fournaise et 347 al. ${ }^{[45]}, \mathrm{D}_{50}$ of whole cow's milk powder produced in similar spray-drying conditions was 27.7 $348 \mu \mathrm{m}$ with a span of 3.0, which is consistent with the present study. At last, the higher total solids 349 of feed cow's milk may have limited particle shrinkage during drying owing to the faster 350 solidification of surface-active molecules located at the droplet/particle surface (caused by the 351 higher molecular concentration at the droplet/particle surface and the lower mass transfer inside 352 the droplet/particle due to its higher viscosity), thus also acting in favor of higher particle size.

353 Significant differences were obtained for the granulometric parameters of spray-dried powders, 354 both owing to milk type and spray-drying conditions. No significant influence of spray-drying conditions was observed for dromedary skim milk powders. However, when increasing the air 356 outlet temperature, cow's skim milk powders presented slightly higher median particle sizes. 357 The difference was statistically significant, with median particle size of $17.09 \mu \mathrm{m}$ at $75^{\circ} \mathrm{C}$ air 358 outlet temperature and $19.19 \mu \mathrm{m}$ at $85^{\circ} \mathrm{C}$ air outlet temperature for cow's skim milk powders.

359 Ogolla et al. ${ }^{[22]}$ have reported that an increase in inlet air temperature and a decrease in milk 360 flow rate caused the formation of smaller particles. However, the effect of drying temperature 361 was different in our study. This difference could be attributed to the fact that a higher drying 
temperature accelerates the drying rate of droplets, promoting the fast formation of a crust at their surface, and therefore limit shrinkage, which leads to larger particles. ${ }^{[46]}$

The span showed small significant differences between all spray-dried milk powders. However, there is no marked effect of either the milk type or the spray-drying conditions on the span. Indeed, for skim dromedary milk powders, the increase in the air outlet temperature resulted in a slight decrease in the span values from 1.93 to 1.76 . For skim cow's milk powders, span values were about 1.75 and 1.81 at 75 and $85^{\circ} \mathrm{C}$ air outlet temperature, respectively.

\section{Color of skim dromedary and cow's milk powders}

Table 4 displays the color parameters of skim dromedary and cow's milk powders. Whatever the spray-drying conditions and the milk type, the produced powders were very bright ( $\mathrm{L}^{*}$ was elevated), had a low color saturation $\left(\mathrm{C}^{*}\right.$ was very low), and their main color was green-yellow (owing to $\mathrm{H}^{\circ}$ values). Hence, spray-dried powders appeared relatively white, as such a lowly-saturated color cannot be detected by the human eye at this high level of brightness. Skim cow's milk powders were significantly yellower than skim dromedary milk powders whatever the spray-drying conditions. This could probably be due to the higher residual fat content in skim cow's milk powders. This could probably be attributed to the lower content in $\beta$-carotene of skim dromedary milk powders compared to skim cow's milk powders. $[47,48]$

Although spray-drying at higher air temperature seemed not to affect brightness and main color, it slightly increased color saturation, which could contribute to the promotion of consumer acceptability of these powders. This increase in powder color saturation may be related to the Maillard reaction susceptible to occur between milk proteins and lactose, known to be enhanced at higher temperature. ${ }^{[34,49,50]}$ These findings could also be attributed to the lower moisture content of powders spray-dried at higher temperatures. ${ }^{[22]}$ Similar results were 
previously obtained by Ogolla et al. ${ }^{[22]}$ and Sulieman et al. ${ }^{[18]}$ who investigated the effect of the inlet air temperatures on the color of spray-dried dromedary milk powders. These authors reported that higher inlet drying air temperatures resulted in decreased $\mathrm{L}^{*}$ and hue angles while increasing the $\mathrm{a}^{*}, \mathrm{~b}^{*}$ and chroma values of spray-dried dromedary milk powders.

\section{Morphology and surface appearance of skim dromedary and cow's milk powders}

The scanning electron micrographs of skim dromedary and cow's milk powders are presented in Figure 3. Whatever the spray-drying conditions and the milk type, spray-dried powders appeared as agglomerates of small particles rather than single particles. Small agglomerates with angular and homogeneous shape are visible in Figure 3. Furthermore, the particles had a shriveled appearance as well as an irregular and rough surface, which is the classical shape of skim milk powders. Few pores could be detected at their surface, as pointed out by arrows in Figure $3 \mathrm{D} 2 \mathrm{f}$ and $\mathrm{C} 2 \mathrm{f}$. Habtegebriel et al. ${ }^{[16]}$ reported that, independently of spray-drying conditions, whole dromedary milk powders had a smooth surface, covered by a fat layer, whereas skim dromedary milk powders presented a rougher surface. Similar results were reported by other researchers ${ }^{[23,31]}$ which showed that skim cow's milk powders are composed of flat, wrinkled, and collapsed particles. Furthermore, it has been shown that the presence of surface fat makes particles sticky, enhancing their tendency to form agglomerates ${ }^{[31]}$ This may be the case in our study given the significant fat content of skim dromedary and cow's milk powders probably leading to a high proportion of surface covered by fat ${ }^{[38]}$ and the presence of numerous agglomerates evidenced by SEM images. Habtegebriel et al ${ }^{[16]}$ added that the presence of pores at the particle surface might facilitate water diffusion into the powder, thus enhancing its rehydration ability. Few pores were observable at the surface of particles spray-dried in our study, probably due to the presence of fat, which may be related to the hypothesized stickiness of particles. Furthermore, at higher air outlet temperature, particle 
agglomerates seemed to be denser and the particles appeared more tightly bound (Figure 3: D2e and $(2 \mathrm{c})$.

\section{Rehydration ability of skim dromedary and cow's milk powders}

The reconstitution properties of skim dromedary and cow's milk powders are presented in Table 4. All spray-dried powders could be considered as non-wettable, as their wettability time was higher than $120 \mathrm{~s} .{ }^{[51]}$ This poor wettability can mainly be attributed to the fineness of powders produced with the combination of pilot spray-dryer and bi-fluid nozzle employed in this study ${ }^{[39]}$ In fact, the larger the particle, the higher its weight, and thus the more easily the particle can overcome water surface tension and immerse in water. It has been reported in the literature that a median particle size over $200 \mu \mathrm{m}$ promotes powder wetting. ${ }^{[52]}$ Moreover, it has previously been reported that large particles are more prone to have large surface pores, which results in fast wetting. ${ }^{[38]}$ According to Gaiani et al. ${ }^{[41]}$, the wetting step mainly depends on particle surface charge, surface activity, size, porosity, surface composition (especially, proportion of hydrophilic compounds), contact angle between the powder bed and water, and powder density. Besides, the poor wettability of dairy powders has also often been attributed to the presence of various hydrophobic compounds (lipids, caseins, etc.) at the particle surface. ${ }^{[38]}$ Kim et al. ${ }^{[38]}$ reported a wetting time over 15 min for whole milk powder. Spray-dried powders produced in the current study had a non-negligible fat content, which can lead to a large fraction of the surface covered by lipids and explain their poor wettability.

Moreover, all investigated spray-dried powders could be considered as hardly dispersible. Indeed, their dispersibility indices were well lower than $95 \%{ }^{[51]}$ Spray-drying conditions had an opposite effect on the rehydration behavior of the two types of milk powders. It is evident from Table 4 that dispersibility was positively correlated with the air outlet temperature for skim dromedary milk powder. Actually, the dispersibility index increased from 
$43734.84 \%$ at $75{ }^{\circ} \mathrm{C}$ air outlet temperature to $41.82 \%$ at $85{ }^{\circ} \mathrm{C}$ air outlet temperature. Concerning 438 the air outlet temperature, it had no significant difference on dispersibility indices of skim cow's 439 milk powders. These results could also be attributed to granulometric characteristics of skim 440 dromedary and cow's milk powders. In fact, and generally, the larger the mean particle size, the 441 higher the dispersibility index. ${ }^{[53]}$ According to Chever et al. ${ }^{[29]}$, a rapid dispersion requires 442 particle sizes in the range from 150 to $200 \mu \mathrm{m}$, which is not the case in our study. However, for 443 powders produced in the present study, dispersibility and median particle size were highly 444 positively correlated (Pearson's correlation coefficient of 0.89 ), in agreement with the literature [53]. The higher fat content of cow's milk probably led to the formation of stickier particles, thus more difficult to disperse due to the presence of more interparticular interactions.

In general, milk powders are considered to be soluble if their solubility index is higher than $99 \%{ }^{[51]}$ Solubility is known to be mainly affected by powder composition, especially by

449 the nature and structure of proteins. ${ }^{[54]}$ Skim dromedary and cow's milk powders produced in 450 our study could be considered as fairly soluble, as their solubility indices ranged between 78.31 and $95.26 \%$. Besides, the spray-drying conditions did not have the same effect on the 453 produced at $85^{\circ} \mathrm{C}$ air outlet temperature showed a significantly higher solubility index $(95.26$ $\%)$ than the same powder spray-dried at $85{ }^{\circ} \mathrm{C}$ outlet air temperature $(91.95 \%)$. On the other hand, skim cow's milk powder revealed significantly higher solubility when spray-dried at 75 ${ }^{\circ} \mathrm{C}$ outlet air temperature. These results could be related to the significant lower fat content of 457 skim dromedary milk powders and the difference in particle size distributions of studied 458 powders. Indeed, Pearson's correlation coefficient between solubility and median particle size 459 was 0.66 , indicating a medium positive correlation. Besides, whatever the spray-drying 460 conditions, dromedary skim milk powders had slightly better rehydration properties, which 
462 been reported that spray-drying of whole dromedary milk did not cause any noticeable damage

463 to its protein fraction, resulting in a higher solubility of dromedary milk powder than cow's

464 milk powder ${ }^{[5]}$ Additionally, Anandharamakrishnan et al. ${ }^{[56]}$ reported that increasing the outlet

465 air temperatures causes partial protein denaturation and subsequent protein aggregation, 466 inducing solubility loss, as observed for cow's milk powders produced in the present work.

467 From these results, it can be concluded that increasing air outlet temperature did not improve 468 the rehydration characteristics of dromedary and cow's skim milk powders, as rehydration 469 mainly depends on particle size, which was very little affected when changing the outlet air 470 temperature.

\section{CONCLUSION}

472 This study pointed out that spray-drying is a good technique to stabilize dromedary milk 473 and postpone its use. Spray-drying conditions have a noticeable effect on powder 474 physicochemical properties and rehydration ability. In this study, skim dromedary and cow's 475 milks were spray-dried without prior concentration to avoid introducing another source of 476 process variability. The findings indicated that the outlet drying air temperatures significantly 477 influenced the physical and rehydration properties of obtained powders. Overall, applying an 478 air outlet temperature of $85^{\circ} \mathrm{C}$ led to better chemical and physical properties for both milk 479 powders. Indeed, a higher air outlet temperature $\left(85^{\circ} \mathrm{C}\right)$ resulted in higher spray-drying yields 480 and skim dromedary and cow's milk powders with higher total solid contents and lower water 481 activity, which is favorable for preservation purposes. When increasing the air outlet 482 temperature, skim dromedary and cow's milk powders presented higher median particle sizes. 483 Spray-drying at $85{ }^{\circ} \mathrm{C}$ outlet temperature seemed not to affect powder brightness and main 484 color, but it slightly increased color saturation. The results of the present study revealed that 485 regardless of process conditions and milk type, skim milk powders spray-dried at pilot scale 486 could be considered as non-wettable, hardly dispersible, and fairly soluble. However, slightly 
487 better rehydration properties were obtained for dromedary skim milk powders spray-dried at 85

$488{ }^{\circ} \mathrm{C}$ outlet air temperature. The SEM analysis showed that spray-dried skim milk powders were 489 composed of agglomerates of small particles with angular and homogeneous shapes. This could

490 be detrimental to their flow properties and may result in handling issues when conveying or 491 storing these powders. Therefore, it will be interesting in further research works to investigate 492 the flow properties of skim dromedary and cow's milk powders spray-dried at pilot scale. 493

\section{DISCLOSURE STATEMENT}

496 there are no known conflicts of interest associated with this publication and that there has been 497 no financial support for this work that could have influenced its outcome.

\section{FUNDING}

500 This project was financially supported by the Ministry of Higher Education and

501 Scientific Research of Tunisia through the scholarship program under the project called 502 Mobility to Encourage Young Tunisian Researchers. The authors acknowledge also support of 503 the LIBio by the "Impact Biomolecules" project of the "Lorraine Universite d'Excellence" 504 (Investissements d'avenir - ANR).

\section{NOTE ON CONTRIBUTORS}

506 The authors would like to thank all the LIBio members for their help and support as well 507 as Alexandre LAFLOTTE from the experimental domain of La Bouzule for cow's milk supply.

508 Pr. Leila MAHFOUDHI, Emeritus Teacher of English at the Faculty of Science of Sfax, should 509 also be thanked for proofreading and refining the manuscript language.

\section{REFERENCES}


512 [1] Al-Haj, O.A.; Al-Kanhal, H.A. Compositional, Technological and Nutritional Aspects 513 of Dromedary Camel Milk, Int. Dairy J. 2010, 20, 811-821. 514 https://doi.org/10.1016/j.idairyj.2010.04.003

515 [2] Shamsia, S.M. Nutritional and therapeutic properties of camel and human milks, Int. J. 516 Genet. Mol. Biol. 2009, 1, 52-58. http://www.academicjournals.org/IJGMB

517 [3] El-Agamy, E.I. Effect of heat treatment on camel milk proteins with respect to 518 antimicrobiol factors: a comparison with cow's and buffalo milk proteins, Food Chem. 2000, 519 68, 227-232. https://doi.org/10.1016/S0308-8146(99)00199-5

520 [4] Felfoul, I.; Lopez, C.; Gaucheron, F.; Attia, H.; Ayadi, M.A. Fouling behavior of camel 521 and cow milks under different heat treatments, Food Bioprocess Tech. 2015, 8, 1771 - 1778. 522 https://doi.org/10.1007/s11947-015-1529-5

523 [5] Felfoul, I.; Beaucher, E.; Cauty, C.; Attia, H.; Gaucheron, F.; Ayadi, M.A. Deposit 524 Generation During Camel and Cow Milk Heating: Microstructure and Chemical Composition, 525 Food Bioprocess Tech. 2016, 9, 1268 - 1275. https://doi.org/10.1007/s11947-016-1714-1

526 [6] Attia, H.; Kherouatou, N.; Fakhfakh, N.; Khorchani, T.; Trigui, N. Dromedary Milk Fat: 527 Biochemical, Microscopic and Rheological Characteristics, J. Food Lipids. 2000, 7, 95-112. 528 https://doi.org/10.1111/j.1745-4522.2000.tb00164.x

529 [7] Hailu, Y.; Hansen, E.B.; Seifu, E.; Eshetu, M.; Petersen, M.A.; Lametsch, R.; Rattray, $530 \quad$ F.; Ipsen, R. Rheological and sensory properties and aroma compounds formed during ripening 531 of soft brined cheese made from camel milk, Int. Dairy J. 2018, 81, 122-130. 532 https://doi.org/10.1016/j.idairyj.2018.01.007

533 [8] Berhe, T.; Seifu, E.; Kurtu, M.Y. Physicochemical properties of butter made from camel 534 milk, Int. Dairy J. 2013, 31, 51-54. https://doi.org/10.1016/j.idairyj.2013.02.008 
535 [9] Mudgil, P.; Jumah, B.; Ahmad, M.; Hamed, F.; Maqsood, S. Rheological, micro536 structural and sensorial properties of camel milk yogurt as influenced by gelatin, LWT- Food 537 Sci. Technol. 2018, 98, 646-653. https://doi.org/10.1016/j.lwt.2018.09.008

538 [10] Kilcast, D.; Subramaniam, P. Food and Beverage Stability and Shelf Life. 1st Edn., 539 Woodhead Publishing, Cambridge, UK., ISBN-13: 978-1845697013, 2011, 864.

540 https://www.worldcat.org/title/food-and-beverage-stability-and-shelf-life/oclc/866858740

541 [11] Schuck, P.; Jeantet, R.; Dolivet, A. Analytical Methods for Food and Dairy Powders; 542 John Wiley $\quad \& \quad$ Sons: $\quad$ Oxford $\quad$ (2012).

543 https://onlinelibrary.wiley.com/doi/book/10.1002/9781118307397

544 [12] Jangam, S. V. An Overview of Recent Developments and Some R\&D Challenges

545 Related to Drying of Foods. Dry. Technol. 2011, 29, 1343-1357. DOI: $546 \quad \underline{10.1080 / 07373937.2011 .594378 .}$

547 [13] Birchal, V. S.; Huang, L.; Mujumdar, A. S.; Passos, M. L. Spray Dryers: Modeling and 548 Simulation. Dry. Technol. 2006, 24, 359-371. DOI: 10.1080/07373930600564431.

549 [14] Bellinghausen, R. Spray Drying from Yesterday to Tomorrow: An Industrial 550 Perspective. Dry. Technol. 2019, 37, 612-622. DOI: 10.1080/07373937. 2018.1517778.

551 [15] Schuck, P.; Jeantet, R.; Bhandari, B.; Chen, X.D.; Perrone, I.T.; de Carvalho, A.F.; 552 Fenelon, M.; Kelly, P. Recent advances in spray drying relevant to the dairy industry: A 553 comprehensive critical review, Dry. Technol. 2016, 34, 1773-1790. DOI: $554 \quad 10.1080 / 07373937.2016 .1233114$

555 [16] Habtegebriel, H.; Edward, D.; Wawire, M.; Sila, D.; Seifu, E. Effect of operating 556 parameters on the surface and physico-chemical properties of spray-dried camel milk powders, 557 Food Bioprod. Process. 2018, 112, 137 - 149. https://doi.org/10.1016/j.fbp.2018.09.010 
558 [17] Rahman, M.S.; Al-Hakmani, H.; Al-Alawi, A.; Al-Marhubi, I. Thermal characteristics

559 of freeze-dried camel milk and its major components, Thermochim. Acta. 2012, 549, 116- 123.

560 https://doi.org/10.1016/j.tca.2012.09.005

561 [18] Sulieman, A.M.E.; Elamin, O.M.; Elkhalifa, E.A.; Laleye, L. Comparison of 562 Physicochemical Properties of Spray-Dried Camel's Milk and Cow's Milk Powder, Int. J. Food 563 Sci. Nutr. Eng. 2014, 4, 15-19. DOI: 10.5923/j.food.20140401.03

564 [19] Smits, M.G.; Huppertz, T.; Alting, A.C.; Kiers, J. Composition, constituents and 565 properties of Dutch camel milk, J. camel pract. Res. 2011, 18, 1-6.

566 https://www.milkessence.nl/wp-content/uploads/2018/04/Dutch-camel-080411-opm-

$567 \quad \underline{\text { NIZO.pdf }}$

568 [20] Zouari, A.; Perrone, I.T.; Dolivet, A.; Schuck, P.; Gaucheron, F.; Attia, H.; Ayadi, M.A. 569 Physicochemical properties of spray dried camel milk powder: a comparative study with cow 570 milk powder, EuroDrying'2017 - 6th European Drying Conference-Liège, Belgium, 2017, 19-

57121 June 2017. https://hal.archives-ouvertes.fr/hal-01546433

572 [21] Zouari, A.; Perrone, I.T.; Schuck, P.; Gaucheron, F.; Dolivet, A.; Attia, H.; Ayadi, M.A.

573 Effect of outlet drying temperature and milk fat content on the physicochemical characteristics 574 of spray-dried camel milk powder, Dry. Technol. 2019, 37, 1615-1624. DOI: $575 \quad 10.1080 / 07373937.2018 .1526189$.

576 [22] Ogolla, J.A.; Kulig, B.; Bădulescu, L.; Okoth, M.W.; Esper, G.; Breitenbach, J.; Hensel,

577 O.; Sturm, B. Influence of Inlet Drying Air Temperature and Milk Flow Rate on the Physical, 578 Optical and Thermal Properties of Spray-Dried Camel Milk Powders, Food Bioprocess 579 Technol. 2019, 12, 751-768. https://doi.org/10.1007/s11947-019-2243-5

580 [23] Kelly, G.M.; O’Mahony, J.A.; Kelly, A.L.; Huppertz, T.; Kennedy, D.; O’Callaghan, 581 D.J. Influence of protein concentration on surface composition and physico-chemical properties 
582 of spray-dried milk protein concentrate powders, Int. Dairy J. 2015, 51, 34-40. 583 https://doi.org/10.1016/j.idairyj.2015.07.001

584 [24] A.O.A.C, Official methods of analysis of AOAC International (20th ed.). Rockville, 585 Maryland, USA: AOAC international, 2016.

586 [25] Folch, J.; Lees, M.; Sioane-Staniey, G.A. A simple method for isolation and purification 587 of total lipids from animal tissues, J. Biol. Chem. 1957, 266, 497 - 509. 588 https://www.ncbi.nlm.nih.gov/pubmed/13428781

589 [26] Saricoban, C.; Yilmaz, M.T.; Modelling the Effects of Processing Factors on the 590 Changes in Colour Parameters of Cooked Meatballs Using Response Surface Methodology, 591 World App. Sci. J. 2010, 9, 14-22. http://www.idosi.org/wasj/wasj9(1)/2.pdf

592 [27] ISO, Lait sec et produits laitiers en poudre - Détermination de l'indice d'insolubilité. 593 Norme ISO 8156, 2005. https://www.iso.org/fr/standard/42069.html

594 [28] FIL, Poudres de lait instantanées - Détermination de la dispersibilité et de la 595 mouillabilité. Norme FIL 87, 1979. https://www.iso.org/fr/standard/60474.html

596 [29] Chever, S.; Méjean, S.; Dolivet, A.; Mei, F.; Den Boer, C.M.; Le Barzic, G.; Jeantet, R.; 597 Schuck, P. Agglomeration during spray drying: Physical and rehydration properties of whole 598 milk/sugar mixture powders, LWT - Food Sci Technol. 2017, 83, 33 - 41. 599 https://doi.org/10.1016/j.lwt.2017.05.002

600 [30] Nijdam, J. J., Langrish, T. A. G. An investigation of milk powders produced by a 601 laboratory-scale spray dryer. Dry. Technol. 2005, 23, 1043-1056. 602 https://doi.org/10.1081/DRT200060208.

603 [31] Langrish, T.A.G.; Marquez, N.; Kota, K. An Investigation and Quantitative 604 Assessment of Particle Shape in Milk Powders from a Laboratory-Scale Spray Dryer, Dry. 605 Technol. 2006, 24, 1619-1630. https://doi.org/10.1080/07373930601031133 
606 [32] de Oliveira, A.H.; Cavalcanti Mata, M.E.R.M.; Fortes, M.; Martins Duarte, M.E.; 607 Pasquali, M.; Lisboa, H.M. Influence of spray drying conditions on the properties of whole goat 608 milk, Dry. Technol. 2020, 1-12, https://doi.org/10.1080/07373937.2020.1714647

609 [33] Deeth, H.C.; Hartanto, J. Chemistry of Milk - Role of Constituents in Evaporation and 610 Drying, 2006, 1-27. https://doi.org/10.1002/9781444322729.ch1

611 [34] Roos, Y.H. Water activity and glass transition. In G. V. Barbosa-Canovas, A. J. Fontana, 612 Jr., S. J. Schmidt, T. P. Labuza (Eds.), Water activity in foods: Fundamentals and applications 613 (pp. 29-45). Oxford, UK: Blackwell Publishing, 2007.

614 https://doi.org/10.1002/9780470376454.ch3

615 [35] Petit, J.; Méjean, S.; Accart, P.; Galet, L.; Schuck, P.; Le Floch-Fouéré, C.; Delaplace, 616 G.; Jeantet, R. A dimensional analysis approach for modelling the size of droplets formed by 617 bi-fluid atomisation, J. Food $\quad$ Eng. 2015, $149, \quad 237 \quad-\quad 247$. 618 https://doi.org/10.1016/j.jfoodeng.2014.10.022

619 [36] Normand, V.; Subramaniam, A.; Donnelly, J.; Bouquerand, P.-E. Spray drying 620 thermodynamics and operating conditions, Carbohyd. Polym. 2013, 97, 489-495. 621 https://doi.org/10.1016/j.carbpol.2013.04.096

622 [37] Gallo, L.; Ramírez-Rigo, M.V.; Piña, J.; Bucalá, V. A comparative study of spray-dried 623 medicinal plant aqueous extracts. Drying performance and product quality, Chem. Eng. Res. 624 Des. 2015, 104, 681-694. https://doi.org/10.1016/j.cherd.2015.10.009

625 [38] Kim, E.H.J.; Chen, X.D.; Pearce, D. Surface characterization of four industrial spray626 dried dairy powders in relation to chemical composition, structure and wetting property, 627 Colloids Surf. B. 2002, 26, 197-212. https://doi.org/10.1016/S0927-7765(01)00334-4

628 [39] Guerin, J.; Petit, J.; Burgain, J.; Borges, F.; Bhandari, B.; Perroud, C.; Desobry, S.; 629 Scher, J.; Gaiani, C. Lactobacillus rhamnosus GG encapsulation by spray-drying : Milk proteins 
630 clotting control to produce innovative matrices, J. Food Eng. 2017, 193, 10 - 19.

631 https://doi.org/10.1016/j.jfoodeng.2016.08.008

632 [40] Khanji, A.N.; Michaux, F.; Petit, J.; Salameh, C.; Rizk, T.; Jasniewski, J.; Banon, S.

633 Structure, gelation, and antioxidant properties of curcumin-doped casein micelle powder 634 produced by spray-drying, Food Funct. 2018, 9, 971 - 981. 635 https://pubs.rsc.org/en/content/articlelanding/2018/fo/c7fo01923

636 [41] Gaiani, C.; Ehrhardt, J.J.; Scher, J.; Hardy, J.; Desobry, S.; Banon, S. Surface 637 composition of dairy powders observed by X-ray photoelectron spectroscopy and effects on 638 their rehydration properties, Colloids Surf. B. 2006, 49, 71 - 78. 639 https://doi.org/10.1016/j.colsurfb.2006.02.015

640 [42] Nikolova, Y.; Petit, J.; Sanders, C.; Gianfrancesco, A.; Desbenoit, N.; Frache, G.; 641 Francius, G.; Scher, J.; Gaiani, C. Is it possible to modulate the structure of skim milk particle 642 through drying process and parameters? J. Food Eng. 2014, 142, 179 - 189. 643 https://doi.org/10.1016/j.jfoodeng.2014.05.026

644 [43] Nikolova, Y.; Petit, J.; Gianfrancesco, A.; Sanders, C. F. W.; Scher, J.; Gaiani, C. Impact 645 of Spray Drying Process Parameters on Dairy Powder Surface Composition and Properties. 646 Dry. Technol. 2015a, 33, 1654-1661. DOI: 10.1080/07373937.2015.1060494.

647 [44] Nikolova, Y.; Petit, J.; Sanders, C.; Gianfrancesco, A.; Scher, J.; Gaiani, C. Toward a 648 better determination of dairy powders surface composition through XPS matrices development, 649 Colloids Surf. B. 2015b, 125, 12 - 20. https://doi.org/10.1016/j.colsurfb.2014.11.009

650 [45] Fournaise, T.; Burgain, J.; Perroud, C.; Scher, J.; Gaiani, C.; Petit, J. Impact of 651 formulation on reconsitution and flowability of spray-dried milk powders, Powder Technol. 652 2019. https://doi.org/10.1016/j.powtec.2020.05.085 
653 [46] Kim, E. H.-J.; Chen, X. D.; Pearce, D. Surface Composition of Industrial Spray-Dried 654 Milk Powders. 2. Effects of Spray Drying Conditions on the Surface Composition. J. Food Eng. 655 2009, 94, 169-181. DOI: 10.1016/j.jfoodeng.2008.10.020.

656 [47] Abu-Lehia, I. H. ; Al-Mohizea, I. S. ; El-Behry, M. Studies on the production of ice 657 cream from camel milk products. Aust. J. Dairy Technol. 1989, 44, 31-34. 658 https://core.ac.uk/display/60946451

659 [48] Farah, Z.; Rettenmaier, R.; Atkins, D. Vitamin content in camel milk. Int. J. Vitam. 660 Nutr. Res. 1992, 62, 30-33. https://www.ncbi.nlm.nih.gov/pubmed/1587705

661 [49] Gaiani, C. Etude des mécanismes de réhydratation des poudres laitières [Ressource 662 électronique] : influence de la structure et de la composition des poudres. Mémoire de thèse de 663 doctorat soutenu le 5 juillet 2006. S.1. : Vandoeuvre-les-Nancy : INPL, 2006. https://hal.univ664 lorraine.fr/tel-01752477

665 [50] Sturm, B., Hofacker, W., \& Hensel, O. (2012). Optimizing the drying parameters for 666 hot air-dried apples. Dry. Technol. 2012, 30, 1570-1582. 667 https://doi.org/10.1080/07373937.2012.698439.

668 [51] Haugaard Sorensen, I.; Ktag, J.; Pisecky, J.; Westergaard, V. Méthodes d'analyses des 669 produits laitiers déshydratés. Niro Atomizer, Copenhague, Danemark, 1978.

670 [52] Szulc, K.; Lenart, A. Water vapour adsorption properties of agglomerated baby food 671 powders, J. Food Eng. 2012, 109, 135-141. https://doi.org/10.1016/j.jfoodeng.2011.09.023

672 [53] Börjesson, E.; Innings, F.; Trägårdh, C.; Bergenståhl, B.; Paulsson, M. Evaluation of 673 particle measures relevant for powder bed porosity - A study of spray dried dairy powders, 674 Powder Technol. 2014, 253, 453-463. https://doi.org/10.1016/j.powtec.2013.11.050

675 [54] Himmetagaoglu, A.B.; Erbay, Z. Effects of spray drying process conditions on the 676 quality properties of microencapsulated cream powder, Int. Dairy J. 2018, 88, 60 - 70. 677 https://doi.org/10.1016/j.idairyj.2018.08.004 
678 [55] Smits, M.G.; Huppertz, T.; Alting, A.C.; Kiers, J. Composition, constituents and 679 properties of Dutch camel milk. J. Camel Pract. Res. 2011, 18, 1-6.

680 https://www.milkessence.nl/wp-content/uploads/2018/04/Dutch-camel-080411-opm-

$681 \quad$ NIZO.pdf

682 [56] Anandharamakrishnan, C., Rielly, C. D., Stapley, A. G. F. Effects of Process Variables 683 on the Denaturation of Whey Proteins during Spray Drying. Dry. Technol. 2007, 25, 799684 807. doi:10.1080/07373930701370175 
686 Figure 1. Schema (A) and dimensions (B) of the Micra Spray MS 150 single-effect spray tower.

687 Figure 2. Particle size distributions of skim dromedary and cow's milk powders.

688 Figure 3. Scanning electron micrographs of skim dromedary and cow's milk powders. D1:

689 Dromedary_C1; D2: Dromedary_C2; C1: Cow_C1; C2: Cow_C2. Magnifications: $200 \times(a)$, $690600 \times(b), 2000 \times(c), 4000 \times(d), 10000 \times(e)$, and $45000 \times(f)$. 


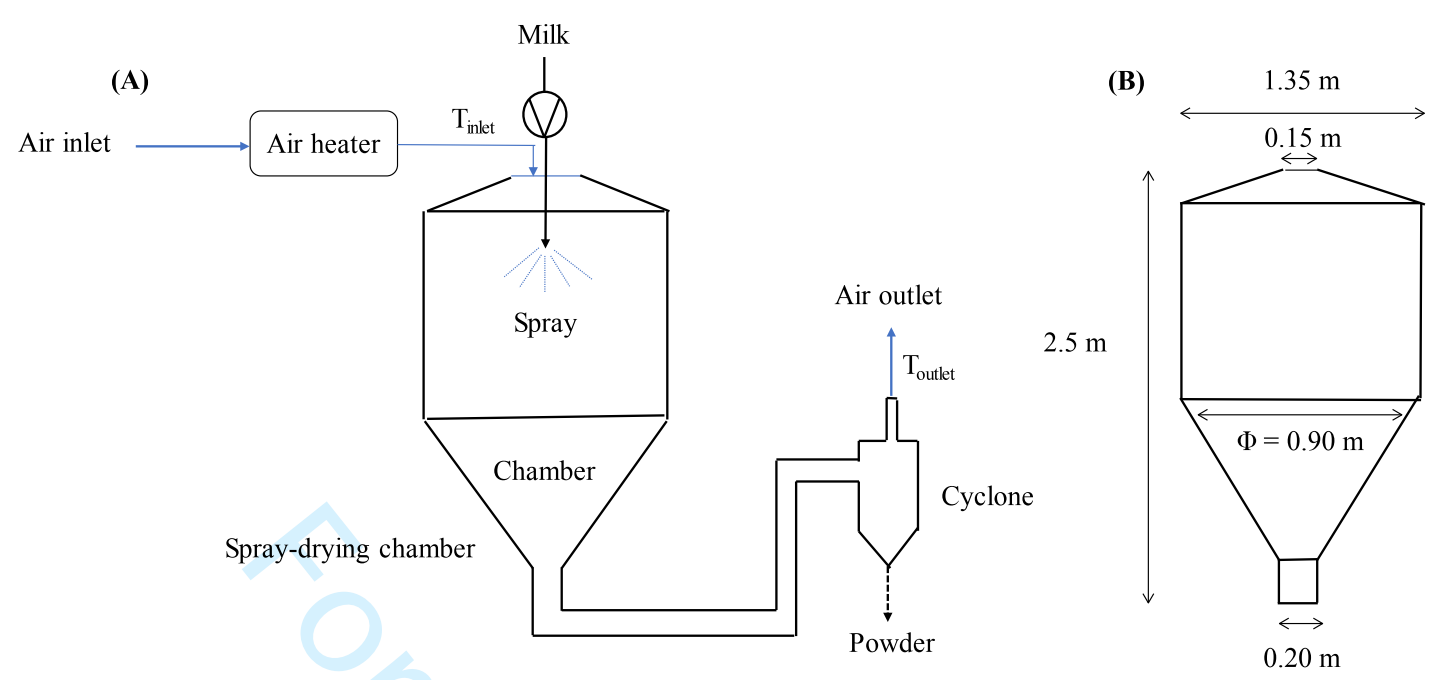

Figure 1 


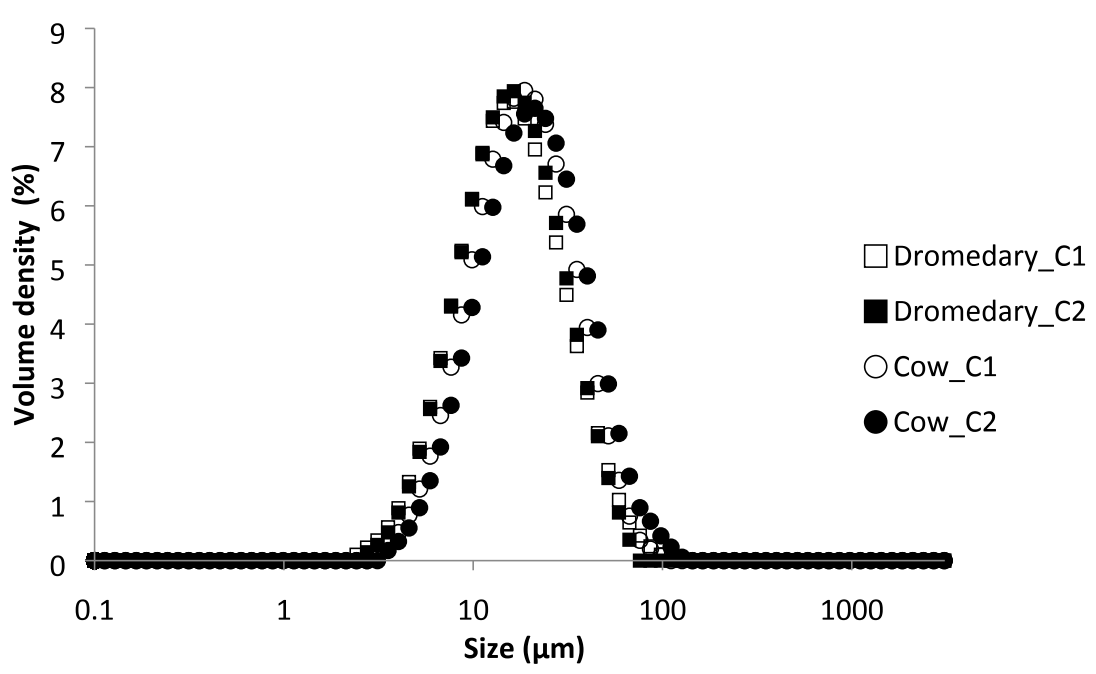

Figure 2 


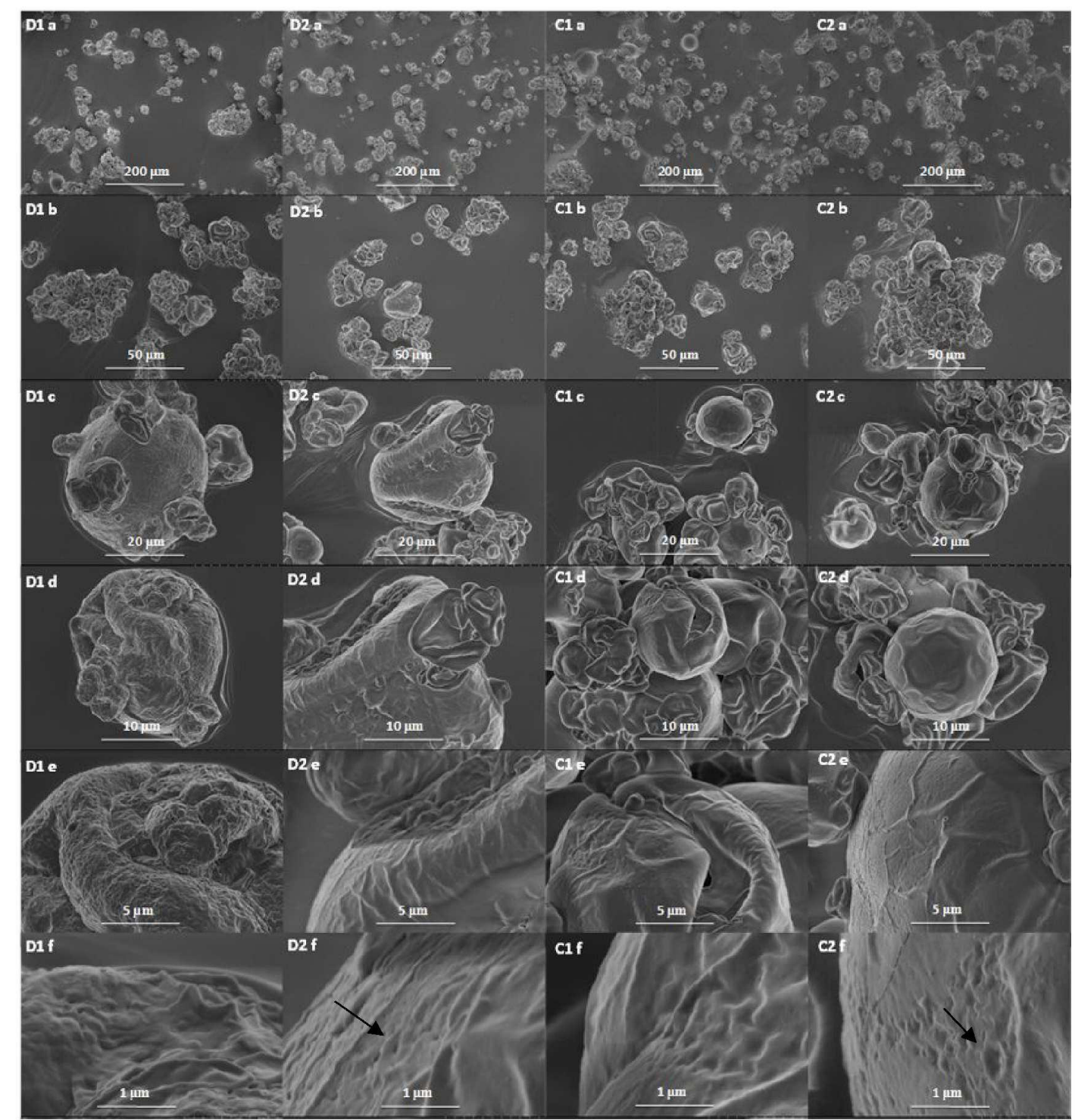

Figure 3 
Table 1. Spray-drying conditions used for the production of skim dromedary and cow's milk powders.

\begin{tabular}{lccc}
\hline Powder sample & $\begin{array}{c}\text { Air inlet } \\
\text { temperature }\end{array}$ & $\begin{array}{c}\text { Air outlet } \\
\text { temperature }\end{array}$ & $\begin{array}{c}\text { Feed flow rate } \\
\left(\mathrm{mL} \cdot \mathrm{min}^{-1}\right)\end{array}$ \\
& $\left({ }^{\circ} \mathrm{C}\right)$ & $\left({ }^{\circ} \mathrm{C}\right)$ & \\
\hline Dromedary_C1 & $230.0 \pm 1.3$ & $74.5 \pm 0.7$ & $74.7 \pm 2.1$ \\
Cow_C1 & $230.4 \pm 1.6$ & $74.4 \pm 0.9$ & $76.5 \pm 2.2$ \\
& & & \\
Dromedary_C2 & $230.3 \pm 1.8$ & $84.3 \pm 1.1$ & $65.4 \pm 3.7$ \\
Cow_C2 & $230.6 \pm 1.3$ & $84.8 \pm 0.8$ & $69.5 \pm 2.9$ \\
\hline
\end{tabular}


Table 2. Proximate composition and dynamic viscosity of skim dromedary and cow's milks.

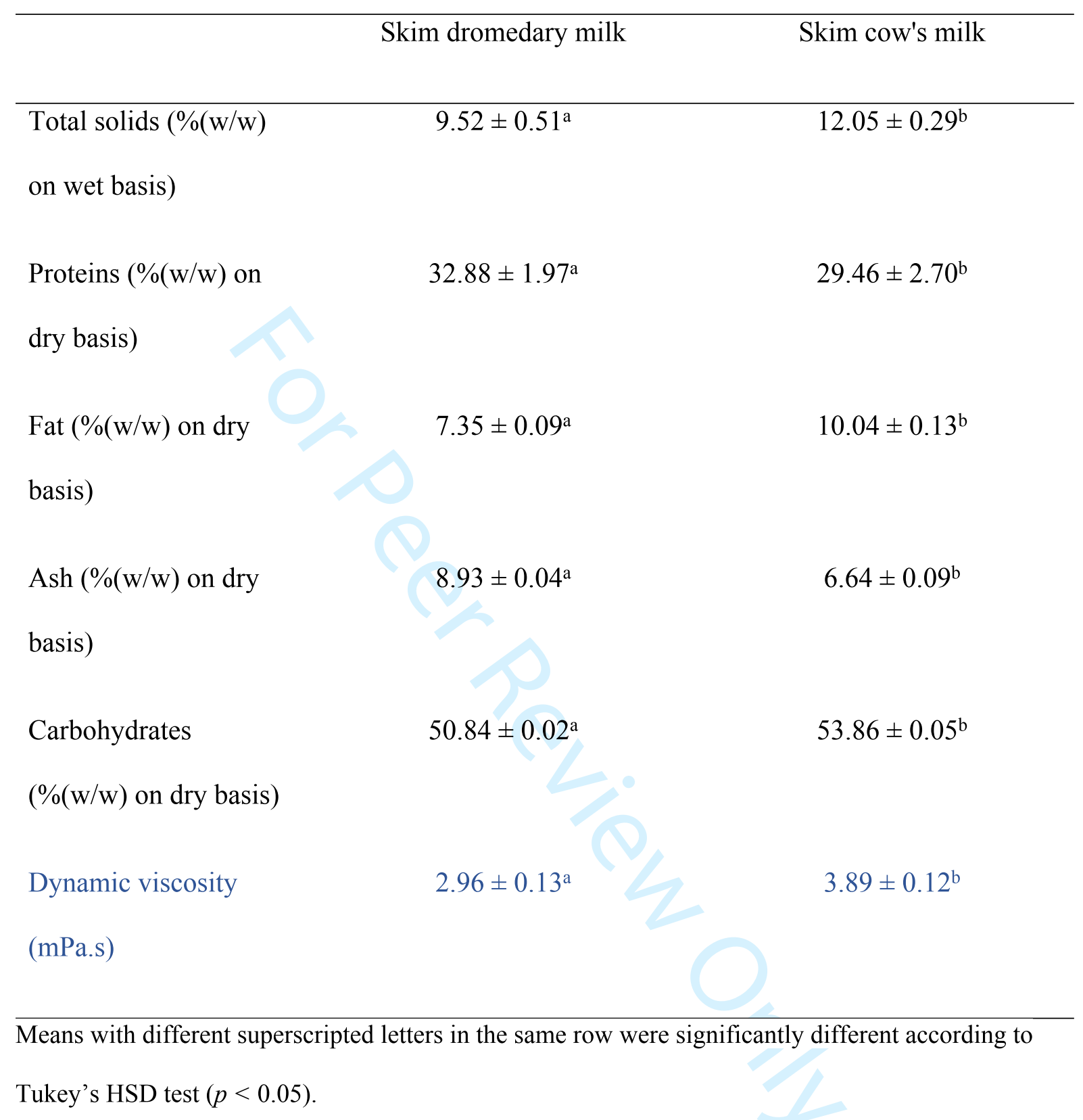


Table 3. Proximate composition, water activity, and spray-drying yield of skim dromedary and cow's milk powders produced in the two spray-drying assays.

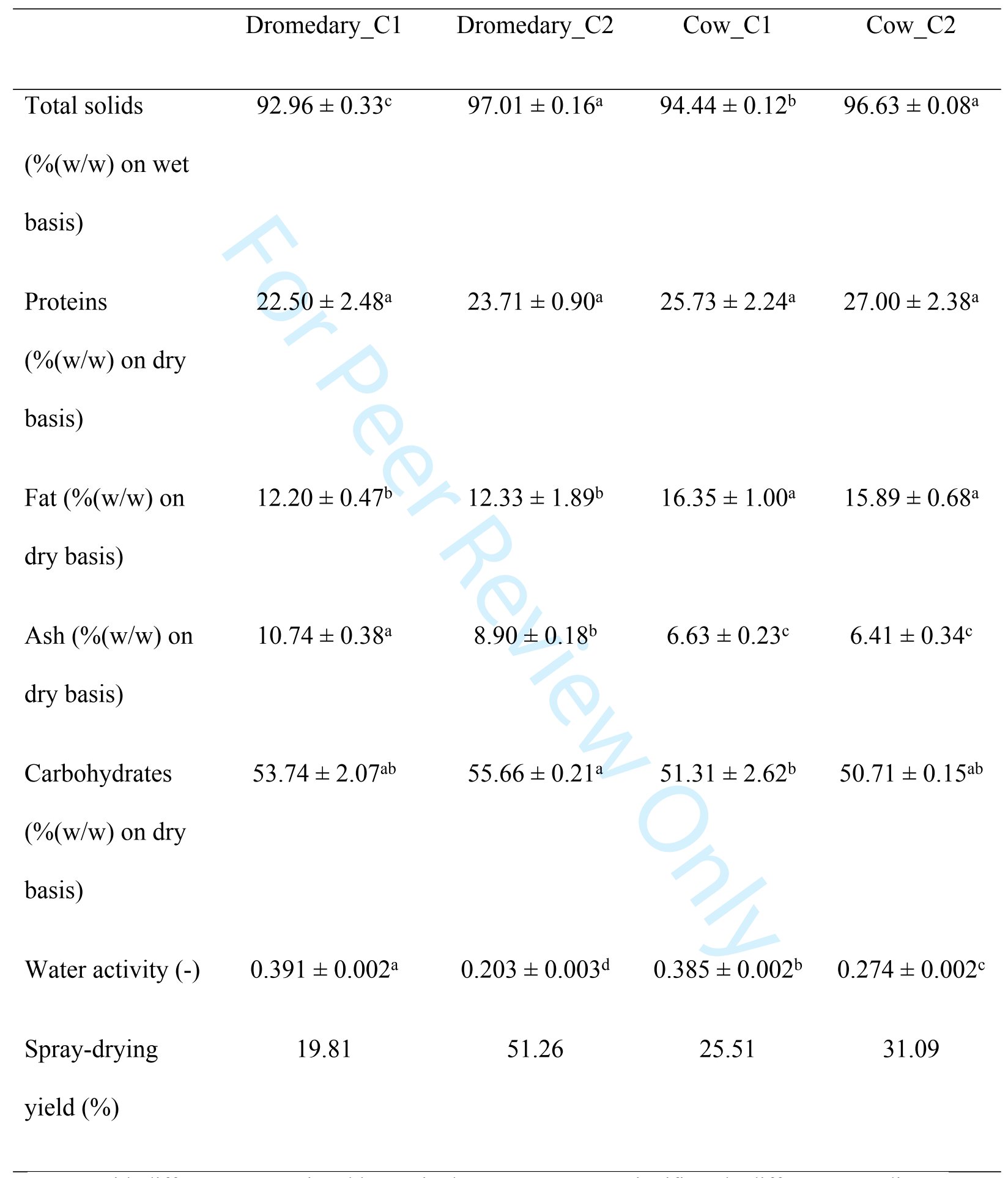

Means with different superscripted letters in the same row were significantly different according to Tukey's HSD test $(p<0.05)$. 
Table 4. Granulometric characteristics, color and rehydration properties of skim dromedary and cow's milk powders.

\begin{tabular}{lcccc}
\hline & Dromedary_C1 & Dromedary_C2 & Cow_C1 & Cow_C2 \\
\hline Granulometric characteristics & & & \\
$\mathrm{D}_{10}(\mu \mathrm{m})$ & $6.41 \pm 0.06^{\mathrm{b}}$ & $6.55 \pm 0.10^{\mathrm{a}}$ & $7.54 \pm 0.06^{\mathrm{c}}$ & $8.28 \pm 0.03^{\mathrm{d}}$ \\
$\mathrm{D}_{50}(\mu \mathrm{m})$ & $14.83 \pm 0.08^{\mathrm{a}}$ & $14.84 \pm 0.21^{\mathrm{a}}$ & $17.09 \pm 0.18^{\mathrm{b}}$ & $19.19 \pm 0.10^{\mathrm{c}}$ \\
$\mathrm{D}_{90}(\mu \mathrm{m})$ & $35.09 \pm 0.36^{\mathrm{c}}$ & $32.68 \pm 0.34^{\mathrm{b}}$ & $37.43 \pm 0.50^{\mathrm{a}}$ & $43.04 \pm 0.33^{\mathrm{d}}$ \\
Span $(-)$ & $1.93 \pm 0.02^{\mathrm{b}}$ & $1.76 \pm 0.01^{\mathrm{a}}$ & $1.75 \pm 0.01^{\mathrm{a}}$ & $1.81 \pm 0.01^{\mathrm{b}}$ \\
Color properties & & & \\
$\mathrm{L}^{*}(-)$ & $94.11 \pm 0.01^{\mathrm{a}}$ & $95.05 \pm 0.10^{\mathrm{c}}$ & $94.30 \pm 0.0^{\mathrm{b}}$ & $94.31 \pm 0.01^{\mathrm{b}}$ \\
$\mathrm{a}^{*}(-)$ & $-1.42 \pm 0.01^{\mathrm{a}}$ & $-2.01 \pm 0.03^{\mathrm{b}}$ & $-2.18 \pm 0.02^{\mathrm{d}}$ & $-2.11 \pm 0.04^{\mathrm{c}}$ \\
$\mathrm{b}^{*}(-)$ & $7.57 \pm 0.01^{\mathrm{d}}$ & $8.87 \pm 0.02^{\mathrm{c}}$ & $10.10 \pm 0.01^{\mathrm{b}}$ & $10.40 \pm 0.01^{\mathrm{a}}$ \\
$\mathrm{C}^{*}(-)$ & $7.70 \pm 0.01^{\mathrm{d}}$ & $9.10 \pm 0.03^{\mathrm{c}}$ & $10.33 \pm 0.01^{\mathrm{b}}$ & $10.61 \pm 0.01^{\mathrm{a}}$ \\
$\left.\mathrm{H}^{\circ}{ }^{\circ}\right)$ & $100.63 \pm 0.07^{\mathrm{a}}$ & $102.78 \pm 0.13^{\mathrm{d}}$ & $102.17 \pm 0.08^{\mathrm{c}}$ & $101.45 \pm 0.19^{\mathrm{b}}$
\end{tabular}

Rehydration properties

Wetting time (s) $\quad>1800 \quad>1800 \quad>1800 \quad>1800$

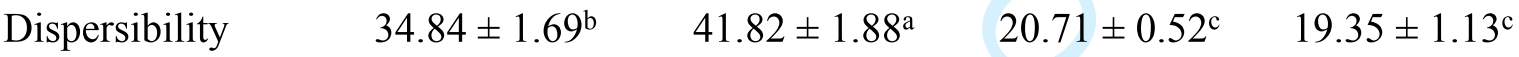

index $(\%)$

Solubility index $\quad 91.95 \pm 0.36^{\mathrm{b}} \quad 95.26 \pm 0.87^{\mathrm{a}} \quad 88.00 \pm 0.36^{\mathrm{c}} \quad 78.31 \pm 2.64^{\mathrm{d}}$

$(\%)$

$\overline{\text { Means with different superscripted letters in the same row were significantly different according to }}$ Tukey's HSD test $(p<0.05)$. 